\title{
BRIEF EXAMINATION OF THE ANTIMICROBIAL ACTIVITY OF PHENOLIC MANNICH BASES DERIVED FROM BUTYLATED HYDROXYANISOLE
}

\author{
GHEORGHE ROMAN $^{1 *}$, IRINA ROŞCA ${ }^{2}$ \\ ${ }^{I}$ Department of Inorganic Polymers, "Petru Poni" Institute of Macromolecular Chemistry, 41A Gr. Ghica Vodă Alley, \\ 700487, Iaşi, Romania \\ ${ }^{2}$ Centre of Advanced Research in Bionanoconjugates and Biopolymers (IntelCentru), "Petru Poni" Institute of \\ Macromolecular Chemistry, 41A Gr. Ghica Vodă Alley, 700487, Iaşi, Romania
}

*corresponding author: gheorghe.roman@icmpp.ro

\begin{abstract}
The aminomethylation of the well-known antioxidant butylated hydroxyanisole (BHA) was explored. A small library comprising eleven tertiary Mannich bases derived from BHA as substrate and piperidines, piperazines and other various secondary amines as amine reagents in aminomethylation has been synthesized and structurally characterized. The antimicrobial activity of these hitherto unknown derivatives of BHA against two bacterial strains (Escherichia coli and Staphylococcus aureus) and one fungal strain (Candida albicans) has been investigated. In a preliminary evaluation using the disk diffusion technique, none of the candidates exhibited significant antimicrobial activity at $100 \mathrm{mg} / \mathrm{mL}$.
\end{abstract}

\section{Rezumat}

A fost studiată aminometilarea cunoscutului antioxidant hidroxianisol butilat (BHA). O mică colecţie conţinând unsprezece baze Mannich terţiare derivate din BHA ca substrat şi piperidine, piperazine şi alte amine secundare ca reactant aminic în reacţia de aminometilare a fost sintetizată şi caracterizată din punct de vedere structural. A fost investigată activitatea antimicrobiană față de două tulpini bacteriene (Escherichia coli și Staphylococcus aureus) şi o tulpină levurică (Candida albicans) a acestor compuşi care nu au fost raportaţi în literatura de specialitate până acum. Ca urmare a evaluării preliminare folosind metoda de difuzie a discurilor, s-a stabilit că nici unul dintre aceşti candidaţi nu prezintă acţiune antimicrobiană semnificativă la o concentraţie de $100 \mathrm{mg} / \mathrm{mL}$.

Keywords: aminomethylation, Mannich bases, BHA, antimicrobial

\section{Introduction}

Butylated hydroxyanisole (BHA) is a well-known synthetic antioxidant featuring a sterically hindered phenol structure, which has been mainly used in food and pharmaceutical products as additive. In addition to its industrial uses, several biological activities have been disclosed. For example, BHA exhibited antioxidant activity in microsomal and linoleate systems [27], exerted $\mathrm{Ca}^{2+}$ antagonistic effects in rat aorta rings [7] and inhibited L-type $\mathrm{Ca}^{2+}$ current in guinea pig gastric muscle strips [8]. Also, a moderate cytotoxic activity has been reported for BHA. The cytotoxic effects of BHA have been mostly attributed to apoptosis [20], although caspasedependent apoptosis and glutathione depletion [17], along with single-strand DNA breakage [33] may also contribute to the reported cytotoxicity of BHA. Moreover, the broad antimicrobial properties of BHA have been long known. Thus, five Bacillus strains were inhibited by 75 - 100 ppm of BHA in nutrient broth, but the levels required for growth inhibition of Bacillus cereus in cooked rice or strained chicken were between 10 and 50 times higher than those in laboratory media [28]. Concentrations of $150-200$ ppm of BHA, and 150 ppm BHA or above totally inhibited the growth of Salmonella typhimurium and Staphylococcus aureus, respectively, in trypticase soy broth [4]. A thorough study investigated the action of BHA (along with other antioxidants) against a large number of bacteria, and found that it inhibited gram-positive bacteria more than gram-negative bacteria [9]. As little as $150 \mathrm{ppm}$ BHA significantly reduced the number of colonies formed on agar media by Saccharomyces cerevisiae compared with controls [6], whereas the presence of BHA was shown to affect the cultures of six strains of Aspergillus on agarose [13]. Aminomethylation is a major process in organic synthesis that allows the substitution of an active hydrogen atom in an organic substrate with an aminomethyl function (and less often an aminoalkyl moiety) in one step [29]. Also known as the Mannich reaction, aminomethylation covers the derivatization of structurally diverse substrates with an aminomethyl function through direct reaction with formaldehyde as the carbonyl 
component and various primary or secondary amines as amine reagents to generate secondary or tertiary amines generally referred to as Mannich bases [30]. Aminomethylation has been extensively used as a synthetic tool in medicinal chemistry to produce pharmacologically relevant compounds, prodrugs, or intermediates in the preparation of known drugs $[2,25]$. Among the types of substrates that can be subjected to aminomethylation, phenols represent starting materials for antimalarials such as aminomethylphenol-tethered 4-aminoquinolines amodiaquine, amopyroquine and analogues (e.g. pyronaridine) [12] or for cytotoxic agents derived from phenolic chalcones $[31,34]$ or lawsone $[3,14]$. In addition, phenolic Mannich bases derived from 3-hydroxy4H-pyran-4-ones (i.e. allomaltol, kojic acid, chlorokojic acid) have been investigated as potential antibacterial agents [5, 32] or antiviral candidates [11]. Aminomethylation of BHA has been barely described in the literature. In one of these studies, the Mannich bases that were obtained from BHA using morpholine and 2,6-dimethylmorpholine as amine reagents have been reported to show interesting diuretic activities [15], whereas a later study investigated the Calkylation of 2-(methylamino)naphthalene with the dimethylamine Mannich base of BHA as a step towards the synthesis of spiranes [16]. The scarcity of reports involving aminomethylated BHA derivatives prompted us to thoroughly investigate their synthesis and generate a medium-size collection of such Mannich bases through the variation of the amine reagent. As a part of our continuous endeavour to broaden the knowledge pertaining to the chemistry [21-24] and biological uses of phenolic Mannich bases [26], the present paper reports the synthesis, characterization and evaluation of antibacterial activity of aminomethylated BHA derivatives.

\section{Materials and Methods}

\section{Chemistry}

All chemical reagents were obtained from SigmaAldrich and were used without prior purification. Melting points were recorded on a Mel-Temp II apparatus and are uncorrected. ${ }^{1} \mathrm{H}$ NMR spectra were recorded on a Bruker Avance 400-MHz spectrometer at room temperature. The signals owing to residual protons in the deuterated solvents were used as internal standards for the ${ }^{1} \mathrm{H}$ NMR spectra. The chemical shifts for the carbon atoms are given relative to $\mathrm{CDCl}_{3}$ $(\delta=77.16 \mathrm{ppm})$ or $\mathrm{CD}_{3} \mathrm{OD}(\delta=49.00 \mathrm{ppm})$. Highresolution mass spectra were obtained on an Applied Biosystems/MDS Sciex QSTAR XL spectrometer equipped with an Agilent HP1100 Cap-LC system. Elemental analysis was conducted on a PerkinElmer 2400 Series II CHNS/O system, and the results were within $\pm 0.4 \%$ of theoretical values.
General procedure for the synthesis of Mannich bases 3-13

A mixture of commercially available BHA (900 mg, 5 mmoles), secondary amine (5 mmoles), and $37 \%$ formaldehyde ( $487 \mathrm{mg}, 530 \mu \mathrm{L}, 6$ mmoles) in $96 \%$ ethanol $(5 \mathrm{~mL})$ was kept at room temperature for 3 days. The solid that separated was filtered and recrystallized. Alternatively, if no crystalline precipitate had separated after 3 days, the solvent was removed under reduced pressure, and the residue partitioned between chloroform $(20 \mathrm{~mL})$ and $5 \% \mathrm{H}_{2} \mathrm{SO}_{4}(20 \mathrm{~mL})$. The organic phase was further extracted with $5 \%$ $\mathrm{H}_{2} \mathrm{SO}_{4}(10 \mathrm{~mL})$, and then the combined aqueous phase was washed with chloroform $(15 \mathrm{~mL})$. The aqueous phase was treated with saturated $\mathrm{Na}_{2} \mathrm{CO}_{3}$ solution until $\mathrm{pH} 8$, and then it was extracted with chloroform $(2 \times$ $20 \mathrm{~mL}$ ). The chloroform phase was washed with water $(30 \mathrm{~mL})$ and brine $(15 \mathrm{~mL})$, and dried over anhydrous $\mathrm{Na}_{2} \mathrm{SO}_{4}$. The residue resulted after the solvent had been removed under reduced pressure was recrystallized from the appropriate solvent.

2-t-Butyl-4-methoxy-6-(morpholin-4-ylmethyl)phenol 3. Colourless crystals (507 mg, 41\%), mp 91 $92^{\circ} \mathrm{C}$ (ethanol); ${ }^{1} \mathrm{H} \mathrm{NMR}\left(\mathrm{CDCl}_{3}, 400 \mathrm{MHz}\right), \delta: 1.40$ (s, 9H), 2.55 (br s, 4H), 3.66 (s, 2H), 3.74 (br s, 7H), $6.42(\mathrm{~d}, J=3.2 \mathrm{~Hz}, 1 \mathrm{H}), 6.81(\mathrm{~d}, J=3.2 \mathrm{~Hz}, 1 \mathrm{H})$, $10.38(\mathrm{~s}, 1 \mathrm{H}) ;{ }^{13} \mathrm{C} \mathrm{NMR}\left(\mathrm{CDCl}_{3}, 100 \mathrm{MHz}\right), \delta: 29.5$, 35.0, 52.8, 55.8, 62.5, 66.9, 111.4, 113.0, 121.3, 138.0, 150.4, 151.9; Anal. calcd. for $\mathrm{C}_{16} \mathrm{H}_{25} \mathrm{NO}_{3}$ : C 68.79, H 9.02, N 5.01. Found: C 68.88, H 8.93, N 5.08; HRMS (EI), $m / z$ : calcd. for $\mathrm{C}_{16} \mathrm{H}_{25} \mathrm{NO}_{3}: 279.1834$ $\left(\mathrm{M}^{+}\right)$. Found: 279.1841 .

2-t-Butyl-4-methoxy-6-(piperidin-1-ylmethyl)phenol 4. Colourless crystals (1025 mg, 74\%), mp $104-105^{\circ} \mathrm{C}$ (ethanol); ${ }^{1} \mathrm{H}$ NMR $\left(\mathrm{CDCl}_{3}, 400 \mathrm{MHz}\right), \delta: 1.40(\mathrm{~s}$, 9H), 1.49 (br s, 2H), 1.57 - 1.68 (m, 4H), 2.48 (br s, $4 \mathrm{H}), 3.61(\mathrm{~s}, 2 \mathrm{H}), 3.74(\mathrm{~s}, 3 \mathrm{H}), 6.40(\mathrm{~d}, J=2.8 \mathrm{~Hz}$, $1 \mathrm{H}), 6.78(\mathrm{~d}, J=2.8 \mathrm{~Hz}, 1 \mathrm{H}) ;{ }^{13} \mathrm{C} \mathrm{NMR}\left(\mathrm{CDCl}_{3}\right.$, $100 \mathrm{MHz}), \delta$ : 24.2, 25.9, 29.5, 34.9, 53.8, 55.8, 62.8, 111.2, 112.5, 122.3, 137.7, 151.0, 151.7; Anal. calcd. for $\mathrm{C}_{17} \mathrm{H}_{27} \mathrm{NO}_{2}$ : C 73.61, H 9.81, N 5.05. Found: C 73.67, H 9.69, N, 4.98; HRMS (EI), $\mathrm{m} / \mathrm{z}$ : calcd. for $\mathrm{C}_{17} \mathrm{H}_{27} \mathrm{NO}_{2}$ : $277.2042\left(\mathrm{M}^{+}\right)$. Found: 277.2047.

2-t-Butyl-4-methoxy-6-(4-methylpiperidin-1-ylmethyl)phenol 5. Colourless crystals (875 mg, 60\%), mp 68 $69^{\circ} \mathrm{C}$ (ethanol); ${ }^{1} \mathrm{H} \mathrm{NMR}\left(\mathrm{CDCl}_{3}, 400 \mathrm{MHz}\right), \delta: 0.94$ $(\mathrm{d}, J=6.4 \mathrm{~Hz}, 3 \mathrm{H}), 1.20-1.33(\mathrm{~m}, 2 \mathrm{H}), 1.37-1.49$ $(\mathrm{m}, 10 \mathrm{H}), 1.66(\mathrm{~d}, J=13.2 \mathrm{~Hz}, 2 \mathrm{H}), 2.04(\mathrm{t}, J=11.4$ $\mathrm{Hz}, 2 \mathrm{H}), 2.94$ (d, $J=11.6 \mathrm{~Hz}, 2 \mathrm{H}), 3.62(\mathrm{~s}, 2 \mathrm{H}), 3.74$ $(\mathrm{s}, 3 \mathrm{H}), 6.40(\mathrm{~d}, J=3.2 \mathrm{~Hz}, 1 \mathrm{H}), 6.78(\mathrm{~d}, J=3.2 \mathrm{~Hz}$, $1 \mathrm{H}) ;{ }^{13} \mathrm{C} \mathrm{NMR}\left(\mathrm{CDCl}_{3}, 100 \mathrm{MHz}\right), \delta: 21.8,29.5,30.8$, 34.2, 34.9, 53.2, 55.8, 62.4, 111.2, 112.5, 122.4, 137.7, 151.0, 151.7; Anal. calcd. for $\mathrm{C}_{18} \mathrm{H}_{29} \mathrm{NO}_{2}$ : C 74.18, H 10.03, N, 4.81. Found: C 74.08, H 9.91, N 4.90; HRMS (EI), $m / z$ : calcd. for $\mathrm{C}_{18} \mathrm{H}_{29} \mathrm{NO}_{2}: 291.2198\left(\mathrm{M}^{+}\right)$; Found: 291.2206. 
FARMACIA, 2019, Vol. 67, 6

6-(4-Benzylpiperidin-1-ylmethyl)-2-t-butyl-4methoxyphenol 6. Colourless crystals $(1160 \mathrm{mg}$, $63 \%), \mathrm{mp} 125-126^{\circ} \mathrm{C}$ (ethanol); ${ }^{1} \mathrm{H}$ NMR $\left(\mathrm{CDCl}_{3}\right.$, $400 \mathrm{MHz}), \delta: 1.27-1.42(\mathrm{~m}, 2 \mathrm{H}), 1.41(\mathrm{~s}, 9 \mathrm{H})$, $1.52-1.64(\mathrm{~m}, 1 \mathrm{H}), 1.68(\mathrm{~d}, J=13.2 \mathrm{~Hz}, 2 \mathrm{H}), 2.00$ $(\mathrm{t}, J=11.6 \mathrm{~Hz}, 2 \mathrm{H}), 2.55(\mathrm{~d}, J=7.2 \mathrm{~Hz}, 2 \mathrm{H}), 2.96$ (d, $J=12.0 \mathrm{~Hz}, 2 \mathrm{H}), 3.62$ (s, 2H), 3.73 (s. 3H), 6.39 $(\mathrm{d}, J=3.2 \mathrm{~Hz}, 1 \mathrm{H}), 6.79(\mathrm{~d}, J=3.2 \mathrm{~Hz}, 1 \mathrm{H}), 7.11$ $7.23(\mathrm{~m}, 3 \mathrm{H}), 7.25$ - $7.32(\mathrm{~m}, 2 \mathrm{H}) ;{ }^{13} \mathrm{C} \mathrm{NMR}\left(\mathrm{CDCl}_{3}\right.$, $100 \mathrm{MHz}$ ), $\delta: 29.5,32.2,35.0,37.9,43.1,53.1,55.8$, 62.4, 111.2, 112.5, 122.3, 126.0, 128.4, 129.2, 137.7, 140.6, 150.9, 151.7; Anal. calcd. for $\mathrm{C}_{24} \mathrm{H}_{33} \mathrm{NO}_{2}$ : C 78.43, H 9.05, N 3.81. Found: C 78.56, H 8.94, N 3.92; HRMS (EI), $m / z$ : calcd. for $\mathrm{C}_{24} \mathrm{H}_{33} \mathrm{NO}_{2}: 367.2511\left(\mathrm{M}^{+}\right)$. Found: 367.2520 .

2-t-Butyl-4-methoxy-6-(4-methylpiperazin-1-ylmethyl)phenol 7. Colourless crystals (818 mg, 56\%), mp 83 $84^{\circ} \mathrm{C}$ (ethanol); ${ }^{1} \mathrm{H} \mathrm{NMR}\left(\mathrm{CDCl}_{3}, 400 \mathrm{MHz}\right), \delta: 1.40$ (s, 9H), 2.31 (s, 3H), 2.54 (br s, 8H), $3.66(\mathrm{~s}, 2 \mathrm{H})$, $3.74(\mathrm{~s}, 3 \mathrm{H}), 6.42(\mathrm{~d}, J=3.2 \mathrm{~Hz}, 1 \mathrm{H}), 6.80(\mathrm{~d}, J=3.2$ $\mathrm{Hz}, 1 \mathrm{H}), 10.63$ (br s, $1 \mathrm{H}) ;{ }^{13} \mathrm{C} \mathrm{NMR}\left(\mathrm{CDCl}_{3}, 100\right.$ $\mathrm{MHz}), \delta$ : 29.5, 34.9, 46.0, 52.4, 55.0, 55.8, 62.0, 111.2, 112.8, 121.8, 137.8, 150.6, 151.8; Anal. calcd. for $\mathrm{C}_{17} \mathrm{H}_{28} \mathrm{~N}_{2} \mathrm{O}_{2}$ : C 69.83, H 9.65, N 9.58. Found: C 69.70, H 9.52, N 9.64; HRMS (EI), $\mathrm{m} / z$ : calcd. for $\mathrm{C}_{17} \mathrm{H}_{28} \mathrm{~N}_{2} \mathrm{O}_{2}$ : $292.2151\left(\mathrm{M}^{+}\right)$. Found: 292.2144.

6-(4-Benzylpiperazin-1-ylmethyl)-2-t-butyl-4-

methoxyphenol hydrochloride 8 . The oil resulted after chloroform had been removed was dissolved in abs. ethanol $(5 \mathrm{~mL})$ and treated with an excess of saturated solution of $\mathrm{HCl}$ in anhydrous diethyl ether to afford the corresponding hydrochloride. Colourless crystals $(884 \mathrm{mg}, 48 \%)$, mp $242-244^{\circ} \mathrm{C}$ (darkens at $216-220^{\circ} \mathrm{C}$ ) (ethanol); ${ }^{1} \mathrm{H}$ NMR $\left(\mathrm{CD}_{3} \mathrm{OD}, 400\right.$ $\mathrm{MHz}), \delta: 1.40$ (s, 9H), 3.69 (br s, 8H), 3.78 (s, 3H), 4.47 (s, 2H), $4.51(\mathrm{~s}, 4 \mathrm{H}), 6.96(\mathrm{~s}, 2 \mathrm{H}), 7.46-7.53(\mathrm{~m}$, $3 \mathrm{H}), 7.60-7.66(\mathrm{~m}, 2 \mathrm{H}) ;{ }^{13} \mathrm{C}$ NMR $\left(\mathrm{CD}_{3} \mathrm{OD}, 100\right.$ $\mathrm{MHz}), \delta: 30.3,36.0,56.2,57.5,61.3,114.8,117.6$, 121.2, 129.3, 130.5, 131.6, 132.6, 144.2, 149.5, 155.5; Anal. calcd. for $\mathrm{C}_{23} \mathrm{H}_{33} \mathrm{ClN}_{2} \mathrm{O}_{2}$ : C 68.21, H 8.21, N 6.92. Found: C 68.46, H 8.38, N 7.20; HRMS (ESI), $m / z$ : calcd. for $\mathrm{C}_{23} \mathrm{H}_{33} \mathrm{~N}_{2} \mathrm{O}_{2}: 369.5285\left([\mathrm{M}+\mathrm{H}]^{+}\right)$. Found: 369.5291.

2-t-Butyl-4-methoxy-6-(4-phenylpiperazin-1-ylmethyl)phenol 9. Colourless crystals $(585 \mathrm{mg}, 33 \%), \mathrm{mp}$ $164-165^{\circ} \mathrm{C}$ (acetone-ethanol); ${ }^{1} \mathrm{H} \mathrm{NMR}\left(\mathrm{CDCl}_{3}\right.$, $400 \mathrm{MHz}$ ), $\delta: 1.40$ (s, 9H), 2.72 (br s, 4H), 3.25 (br s, $4 \mathrm{H}), 3.73$ (s, 2H), $3.76(\mathrm{~s}, 3 \mathrm{H}), 6.45(\mathrm{~d}, J=3.2 \mathrm{~Hz}$, $1 \mathrm{H}), 6.82(\mathrm{~d}, J=3.2 \mathrm{~Hz}, 1 \mathrm{H}), 6.85-6.96(\mathrm{~m}, 3 \mathrm{H})$, 7.24 - $7.31(\mathrm{~m}, 2 \mathrm{H}), 10.50$ (br s, $1 \mathrm{H}) ;{ }^{13} \mathrm{C} \mathrm{NMR}\left(\mathrm{CDCl}_{3}\right.$, $100 \mathrm{MHz}), \delta: 29.5,35.0,49.3,52.4,55.8,62.1,111.4$, $112.9,116.5,120.3,121.7,129.3,138.0,150.5,151.1$, 151.9; Anal. calcd. for $\mathrm{C}_{22} \mathrm{H}_{30} \mathrm{~N}_{2} \mathrm{O}_{2}$ : C 74.54, H 8.53, N 7.90. Found: C 74.63, H 8.44, N 7.98; HRMS (EI), $m / z$ : calcd. for $\mathrm{C}_{22} \mathrm{H}_{30} \mathrm{~N}_{2} \mathrm{O}_{2}: 354.2307\left(\mathrm{M}^{+}\right)$. Found: 354.2314 .
6-(4-(1,3-Benzodioxol-5-ylmethyl)piperazin-1-

ylmethyl)-6-t-butyl-4-methoxyphenol 10. Colourless crystals $(876 \mathrm{mg}, 44 \%), \mathrm{mp} 99-100^{\circ} \mathrm{C}$ (ethanol); ${ }^{1} \mathrm{H} \mathrm{NMR}\left(\mathrm{CDCl}_{3}, 400 \mathrm{MHz}\right), \delta: 1.40(\mathrm{~s}, 9 \mathrm{H}), 2.54$ (br s, 8H), 3.43 (s, 2H), 3.65 (s, 2H), $3.74(\mathrm{~s}, 3 \mathrm{H})$, $5.94(\mathrm{~s}, 2 \mathrm{H}), 6.41(\mathrm{~d}, J=3.2 \mathrm{~Hz}, 1 \mathrm{H}), 6.71-6.77$ $(\mathrm{m}, 2 \mathrm{H}), 6.79(\mathrm{~d}, J=3.2 \mathrm{~Hz}, 1 \mathrm{H}), 6.85(\mathrm{~s}, 1 \mathrm{H})$, 10.73 (br s, $1 \mathrm{H}) ;{ }^{13} \mathrm{C} \mathrm{NMR}\left(\mathrm{CDCl}_{3}, 100 \mathrm{MHz}\right), \delta: 29.5$, 35.0, 52.5, 52.9, 55.8, 62.1, 62.7, 101.0, 108.0, 109.5, 111.4, 112.8, 121.9, 122.3, 132.1, 137.9, 146.8, 147.9, 150.7, 151.9; Anal. calcd. for $\mathrm{C}_{23} \mathrm{H}_{30} \mathrm{~N}_{2} \mathrm{O}_{4}$ : C 69.32, H 7.59, N 7.03. Found: C 69.44, H 7.63, N 6.91; HRMS (EI), $m / z$ : calcd. for $\mathrm{C}_{23} \mathrm{H}_{30} \mathrm{~N}_{2} \mathrm{O}_{4}: 398.2206$ $\left(\mathrm{M}^{+}\right)$. Found: 398.2198 .

2-t-Butyl-4-methoxy-6-(4-(2-pyridinyl)piperazin-1ylmethyl)phenol 11. Colourless crystals $(604 \mathrm{mg}$, $34 \%)$, mp $170-171^{\circ} \mathrm{C}$ (ethanol); ${ }^{1} \mathrm{H}$ NMR $\left(\mathrm{CDCl}_{3}\right.$, $400 \mathrm{MHz}$ ), $\delta: 1.41$ (s, 9H), 2.67 (br s, 4H), 3.57 (br s, $4 \mathrm{H}), 3.71(\mathrm{~s}, 2 \mathrm{H}), 3.75(\mathrm{~s}, 3 \mathrm{H}), 6.44(\mathrm{~d}, J=3.2 \mathrm{~Hz}$, $1 \mathrm{H}), 6.61-6.70(\mathrm{~m}, 2 \mathrm{H}), 6.82(\mathrm{~d}, J=3.2 \mathrm{~Hz}, 1 \mathrm{H})$, $7.45-7.53(\mathrm{~m}, 1 \mathrm{H}), 8.20(\mathrm{dd}, J=1.6$ and $5.2 \mathrm{~Hz}$, 1H), 10.51 (br s, $1 \mathrm{H}) ;{ }^{13} \mathrm{C} \mathrm{NMR}\left(\mathrm{CDCl}_{3}, 100 \mathrm{MHz}\right)$, $\delta$ : 29.6, 35.0, 45.3, 52.3, 55.8, 62.2, 107.3, 111.6, 113.0, 113.9, 121.7, 137.6, 138.1, 148.2, 150.6, 152.0, 159.5; Anal. calcd. for $\mathrm{C}_{21} \mathrm{H}_{29} \mathrm{~N}_{3} \mathrm{O}_{2}$ : C 70.95, H 8.22, N 11.82. Found: C 71.07, H 8.13, N 11.97; HRMS (EI), $m / z$ : calcd. for $\mathrm{C}_{21} \mathrm{H}_{29} \mathrm{~N}_{3} \mathrm{O}_{2}$ : $355.2260\left(\mathrm{M}^{+}\right)$. Found: 355.2261.

2-t-Butyl-6-(dibenzylaminomethyl)-4-methoxyphenol 12. Colourless crystals (584 mg, 30\%), mp $100-101^{\circ} \mathrm{C}$ (ethanol); ${ }^{1} \mathrm{H} \mathrm{NMR}\left(\mathrm{CDCl}_{3}, 400 \mathrm{MHz}\right)$, $\delta: 1.44(\mathrm{~s}, 9 \mathrm{H}), 3.59(\mathrm{~s}, 4 \mathrm{H}), 3.70(\mathrm{~s}, 2 \mathrm{H}), 3.74(\mathrm{~s}$, $3 \mathrm{H}), 6.45(\mathrm{~d}, J=3.2 \mathrm{~Hz}, 1 \mathrm{H}), 6.79(\mathrm{~d}, J=3.2 \mathrm{~Hz}$, 1H), 7.25 - $7.39(\mathrm{~m}, 10 \mathrm{H}), 10.41(\mathrm{~s}, 1 \mathrm{H}) ;{ }^{13} \mathrm{C} \mathrm{NMR}$ $\left(\mathrm{CDCl}_{3}, 100 \mathrm{MHz}\right), \delta: 29.6,35.0,55.9,57.8,58.1$, 111.9, 112.9, 122.7, 127.7, 128.7, 129.8, 137.2, 138.0, 150.4, 152.0; Anal. calcd. for $\mathrm{C}_{26} \mathrm{H}_{31} \mathrm{NO}_{2}$ : C 80.17, H 8.02, N 3.60. Found: C 80.03, H 7.91, N 3.66; HRMS (EI), $m / z$ : calcd. for $\mathrm{C}_{26} \mathrm{H}_{31} \mathrm{NO}_{2}: 389.2355$ $\left(\mathrm{M}^{+}\right)$. Found: 389.2362 .

2-t-Butyl-6-(3,4-dihydro-1H-isoquinolin-2-ylmethyl)4-methoxyphenol 13. Colourless crystals $(846 \mathrm{mg}$, $52 \%), \mathrm{mp} 111-112^{\circ} \mathrm{C}$ (ethanol); ${ }^{1} \mathrm{H} \mathrm{NMR}\left(\mathrm{CDCl}_{3}\right.$, $400 \mathrm{MHz}$ ), $\delta$ : 1.38 (s, 9H), 2.85 (br s, 2H), 2.90 $2.98(\mathrm{~m}, 2 \mathrm{H}), 3.77$ (br s, 5H), 3.83 (s, 2H), 6.48 (d, $J=3.2 \mathrm{~Hz}, 1 \mathrm{H}), 6.83(\mathrm{~d}, J=3.2 \mathrm{~Hz}, 1 \mathrm{H}), 6.99-$ 7.05 (m, 1H), 7.10 - 7.20 (m, 3H), 10.67 (br s, 1H); ${ }^{13} \mathrm{C} \mathrm{NMR}\left(\mathrm{CDCl}_{3}, 100 \mathrm{MHz}\right), \delta: 28.8,29.5,35.0$, 49.8, 55.3, 55.8, 61.7, 111.4, 112.9, 121.9, 126.1, 126.7, 126.8, 128.8, 133.7, 133.8, 138.1, 150.9, 151.9; Anal. calcd. for $\mathrm{C}_{21} \mathrm{H}_{27} \mathrm{NO}_{2}$ : C 77.50, H 8.36, N 4.30. Found: C 77.59, H 8.31, N 4.23; HRMS (EI), $m / z$ : calcd. for $\mathrm{C}_{21} \mathrm{H}_{27} \mathrm{NO}_{2}$ : $325.2042\left(\mathrm{M}^{+}\right)$. Found: 325.2044. Biological evaluation

The antimicrobial activity was determined by disk diffusion method against three different reference strains: Staphylococcus aureus ATCC25923, Escherichia 
coli ATCC25922 and Candida albicans ATCC10231. All microorganisms were stored at $-80^{\circ} \mathrm{C}$ in $20 \%$ glycerol. The bacterial strains were refreshed in Mueller-Hinton broth at $36^{\circ} \mathrm{C}$, and the fungal strain was refreshed on Sabouraud dextrose agar at $36^{\circ} \mathrm{C}$. Microbial suspensions were prepared with these cultures in sterile solution to obtain a turbidity that is optically comparable to that of $0.5 \mathrm{McFarland}$ standards (yielding a suspension containing $1 \times 10^{8}$ $\mathrm{CFU} / \mathrm{mL}$ for all the microorganisms). Volumes of $0.2 \mathrm{~mL}$ from each inoculum were spread onto MuellerHinton agar, and the compounds to be investigated were added after the medium surface had dried. Sterilized paper discs $(6 \mathrm{~mm})$ were placed on the plate. An aliquot $(50 \mu \mathrm{L})$ of the twelve tested compounds (concentration $100 \mathrm{mg} / \mathrm{mL}$ in DMSO) and DMSO as control were added on the paper discs. To estimate the antimicrobial properties of the tested compounds, the growth inhibition was determined under standard conditions after 24 hours of incubation at $36^{\circ} \mathrm{C}$. The diameters of the inhibition zones were measured using Image $\mathbf{J}$ software.

\section{Results and Discussion}

Commercially available BHA is in fact a mixture of regioisomers, namely 2-t-butyl-4-methoxyphenol (3-BHA) 1 (90\%) and 3-t-butyl-4-methoxyphenol (2-BHA) 2 (Figure 1) [18].<smiles>COc1cc(C)c(O)c(C(C)(C)C)c1</smiles>

1

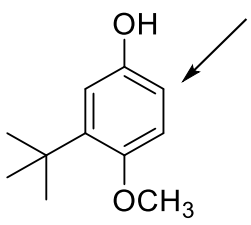

Figure 1.

Structures of the two regiosomers present in commercially available samples of BHA and the potential active sites in aminomethylation

It is conceivable that both isomers take part in the Mannich reaction to afford the corresponding derivatives carrying an aminomethyl function at position 6 . However, because the ratio between the regioisomers in commercial samples of BHA strongly favors 3BHA 1, it seems likely that only a small amount of aminomethylated 2-BHA would form under the conditions of the Mannich reaction. The formation of this by-product could probably be demonstrated by the close inspection of the proton NMR spectrum of the crude reaction mixture. However, because this aspect has never been verified in the course of the experiments conducted for this study, no confirmation or the disproof on the formation of aminomethylated 2-BHA as a minor by-product is available. All the purified samples resulted from the aminomethylation of commercial BHA contained only aminomethylated 3-BHA, which could be construed either as a lack of reactivity of 2-BHA in the Mannich reaction, or as a result of the complete removal (through careful purification of the crude reaction mixture) of the small amount of aminomethylated 2-BHA that could have formed.

A small series of Mannich bases 3-13 derived from butylated hydroxyanisole has been prepared by means of direct aminomethylation. These aminomethylated BHA derivatives feature a tertiary amine moiety, and were obtained using secondary amines as amine reagents in the Mannich reaction, which was performed in ethanol at room temperature, as presented in Figure 2. In order to simplify the scheme, only the reactions of regioisomer $\mathbf{1}$ are represented.<smiles>COc1ccc(O)c(C(C)(C)C)c1</smiles>

1

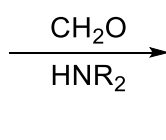

Figure 2.
Synthesis of aminomethylated BHA derivatives by means of direct Mannich reaction

Some of the tertiary Mannich bases 3-13 crystallized from the reaction mixture and were isolated by filtration. The rest were separated by extraction in diluted $\mathrm{H}_{2} \mathrm{SO}_{4}$ followed by treatment of the watersoluble sulphate with a base, and extraction of the free base of aminomethylated BHA in chloroform. The yields of pure aminomethylated derivatives of BHA range from $30 \%$ to over $70 \%$. No attempts to increase the low yields or optimize the reaction conditions by extending the reaction time, or preforming the aminomethylation at a higher temperature, or in different solvents has been made. The lower yields were observed in the case of dibenzylamine and 4-arylpiperazines, and were ascribed to the lesser reactivity of these amines in the Mannich reaction. On the other hand, piperidine appears to be the most reactive amine reagent of all the amines employed in this study. Mannich base $\mathbf{8}$ could not be induced to crystallize, and it was therefore converted into the corresponding hydrochloride by treatment with hydrogen chloride in anhydrous diethyl ether, under exclusion of water. Under the same reaction conditions and after the usual work-up, the Mannich base of BHA derived from hexamethyleneimine could not be isolated.

The structure of the newly synthesized compounds has been investigated by spectroscopy techniques. First, the use of high-resolution mass spectroscopy in positive ion mode has confirmed the accurate mass for all the samples of Mannich bases 3-13 under investigation, corroborated with the correct elemental 
FARMACIA, 2019, Vol. 67, 6

composition. Second, both ${ }^{1} \mathrm{H}$ and ${ }^{13} \mathrm{C}$ NMR have been used to ascertain the structure of the synthesized compounds. A characteristic of the ${ }^{1} \mathrm{H}$ NMR spectra of compounds 3-13 is the signal at approximately $3.6 \mathrm{ppm}$, attributed to the protons in the methylene group bridging the BHA scaffold and the amino moiety. Another typical signal for Mannich bases 3-13 is the off-set peak at $10-11$ ppm integrating for one proton and corresponding to the proton of the phenolic hydroxyl. The high value for this signal clearly indicates a strong hydrogen bonding between the phenolic proton and the nitrogen atom in the amine moiety of the aminomethylated BHA derivatives. Interestingly, this peak is absent in all three piperidinecontaining Mannich bases 4-6. As the peak due the phenolic hydroxyl was evidenced in the ${ }^{1} \mathrm{H}$ NMR spectra of other piperidine-containing phenolic Mannich bases $[1,10,19]$, the piperidine moiety is most likely not the only structural feature accountable for its absence in the spectra of compounds 4-6. The doublets cantered at 6.4 and $6.8 \mathrm{ppm}$ in the aromatic region of the ${ }^{1} \mathrm{H}$ NMR spectra of Mannich bases 3-13 have been assigned to the two remaining protons in the substrate following the introduction of the aminomethyl group. In the carbon spectra of compounds 3-13, the correct number of signals has been observed. The peak at approximately $56 \mathrm{ppm}$ corresponds to the carbon atom in the methylene group linking BHA with the amino moiety. In addition, the most de-shielded signal, situated at approximately $152 \mathrm{ppm}$, has been attributed to the hydroxyl-substituted carbon atom in phenolic Mannich bases 3-13.

The newly synthesized aminomethylated BHA derivatives 3-13 have been evaluated as potential antimicrobial agents. The antimicrobial activity was assessed using the agar disk diffusion method, which involves the addition of the compounds on the culture medium pre-inoculated with the microbial suspension, and measuring the clear zone caused by the growth inhibition around the film disks after $24 \mathrm{~h}$ of incubation. The antimicrobial activity of BHA and Mannich bases 3-13 has been evaluated at a concentration of 100 $\mathrm{mg} / \mathrm{mL}$ against two bacterial strains ( $S$. aureus and Escherichia coli) and one fungal strain (Candida albicans). As expected, BHA was active towards all three microbial strains, the average diameters of the inhibition zones being presented in Table I. The fungal strain appears to be less sensitive to the action of BHA, whereas BHA seems to inhibit mostly the growth of the Gram-positive bacterial strain. No attempt to determine MIC values for BHA toward the microorganism used in the study has been made. On the other hand, Mannich bases 3-13 showed no antimicrobial activity against all the reference strains, even at this high concentration. Because of the lack of antimicrobial activity of aminomethylated BHA derivatives 3-13 in the disk diffusion method, no further determination of a MIC value for individual compounds using the serial dilution method was pursued. Considering that BHA exhibits good antimicrobial properties and the aminomethylated BHA derivatives 3-13 do not, it seems that aminomethylation is not a chemical modification that improves this particular biological activity of BHA.

Table I

Antimicrobial activity of BHA against the three microbial strains used in this study

\begin{tabular}{l|c}
\multicolumn{1}{c|}{ Strain } & Inhibition zone $(\mathrm{cm})$ \\
\hline S. aureus & 1.975 \\
E. coli & 1.180 \\
C. albicans & 0.650 \\
\hline
\end{tabular}

\section{Conclusions}

Aminomethylation of well-known antioxidant BHA has been successfully performed by keeping the substrate, aqueous formaldehyde and various secondary aliphatic amines in ethanol at room temperature for three days. The structure of the resulting tertiary Mannich bases has been confirmed through elemental analysis, NMR spectroscopy and high-resolution mass spectroscopy. Investigation of the antimicrobial activity of BHA confirmed its previously established antimicrobial properties. On the other hand, Mannich bases derived from BHA showed no antimicrobial activity, even at high concentration. This result suggests that the chemical modification of BHA through aminomethylation not only does not lead to derivatives with improved antimicrobial activity, but reduces significantly or even eliminates completely the antimicrobial properties of BHA.

\section{References}

1. Afsah EM, Keshk EM, Abdel-Rahman ARH, Jomah $\mathrm{NF}$, Mannich bases as synthetic intermediates: Convenient synthesis of functionalized 1,2,4-triazepines, 1,4diazepines and 1,5-diazocines. Z Naturforsch B, 2011; 66b: 577-584.

2. Biersack B, Ahmed K, Padhye S, Schobert R, Recent developments concerning the application of the Mannich reaction for drug design. Exp Opin Drug Discov., 2018; 13(1): 39-49.

3. da Silva GB, Neves AP, Vargas MD, Alves WA, Marinho-Filho JDB, Pessoa C, Moraes MO, CostaLotufo LV, Novel 3-(aminomethyl)naphthoquinone mannich base-platinum(IV) complexes: Synthesis, characterization, electrochemical and cytotoxic studies. J Braz Chem Soc., 2013; 24(4): 675-684.

4. Davidson PM, Brekke CJ, Branen AL, Antimicrobial activity of butylated hydroxyanisole, tertiary butylhydroquinone, and potassium sorbate in combination. J Food Sci., 1981; 46(1): 314-316.

5. Emami S, Ghafouri E, Faramarzi MA, Samadi N, Irannejad H, Foroumadi A, Mannich bases of 7piperazinylquinolones and kojic acid derivatives: synthesis, in vitro antibacterial activity and in silico study. Eur J Med Chem., 2013; 68: 185-191. 
6. Eubanks VL, Beuchat LR, Effects of antioxidants on growth, sporulation and pseudomycelium production by Saccharomyces cerevisiae. J Food Sci., 1982; 47(2): 1717-1723.

7. Fusi F, Marazova K, Pessina F, Gorelli B, Valoti M, Frosini M, Sgaragli G, On the mechanisms of the antispasmodic action of some hindered phenols in rat aorta rings. Eur J Pharmacol., 2000; 394: 109-115.

8. Fusi F, Saponara S, Gagov H, Sgaragli G, Effects of some sterically hindered phenols on whole-cell $\mathrm{Ca}(2+)$ current of guinea-pig gastric fundus smooth muscle cells. Br J Pharmacol., 2001; 132(6): 1326-1332.

9. Gailani MB, Fung DYC, Antimicrobial effects of selected antioxidants in laboratory media and in ground pork. J Food Protect., 1984; 47(6): 428-433.

10. Jha A, Paul NK, Trikha S, Cameron TS, Novel synthesis of 2-naphthol Mannich bases and their NMR behaviour. Can J Chem., 2006; 84: 843-853.

11. Karakaya G, Aytemir MD, Özçelik B, Çaliş Ü, Design, synthesis and in vivo/in vitro screening of novel chlorokojic acid derivatives. J Enz Inhib Med Chem., 2013; 28(3): 627-638.

12. Kaur K, Jain M, Reddy RP, Jain R, Quinolines and structurally related heterocycles as antimalarials. Eur J Med Chem., 2010; 45(8): 3245-3264.

13. Lin CCS, Fung DYC, Effect of BHA, BHT, TBHQ and PG on growth and toxigenesis of selected Aspergilli. J Food Sci., 1983; 48(2): 576-580.

14. Mahal K, Ahmad A, Schmitt F, Lockhauserbäumer J, Starz K, Pradhan R, Padhye S, Sarkar FH, Koko WS, Schobert R, Ersfeld K, Biersack B, Improved anticancer and antiparasitic activity of new lawsone Mannich bases. Eur J Med Chem., 2017; 126: 421-431.

15. Meadow JR, Berger JE, Schert RW, Synthesis of Mannich bases having diuretic activity. Chim Ther., 1968; 3: 253-255.

16. Möhrle H, Schake D, Heterocyclische Spirocyclohexadienone aus substituierten Phenolen. Z Naturforsch $B, 1995$; 50b: 1859-1868.

17. Moon HJ, Park WH, Butylated hydroxyanisole inhibits the growth of HeLa cervical cancer cells via caspasedependent apoptosis and GSH depletion. Mol Cell Biochem., 2011; 349(1-2): 179-186.

18. Nanditha B, Prabhasankar P, Antioxidants in bakery products: A review. Crit Rev Food Sci Nutr., 2009; 49(1): 1-27.

19. Neto Í, Andrade J, Pinto Reis C, Salunke JK, Priimagi A, Candeias NR, Rijo P, Multicomponent Petasisborono Mannich preparation of alkylaminophenols and antimicrobial activity studies. Chem Med Chem., 2016; 11(18): 2015-2023.

20. Okubo T, Yokoyama Y, Kano K, Kano I, Molecular mechanism of cell death induced by the antioxidant tert-butylhydroxyanisole in human monocytic leukemia U937 cells. Biol Pharm Bull., 2004; 27(3): 295-302.
21. Roman G, Synthesis and reactivity of Mannich bases. Part XX. Mannich bases derived from 2-naphthol through $\mathrm{N}$-alkylation of pyrazoles, imidazoles and benzimidazoles. C R Acad Bulg Sci., 2005; 58(4): 397-402.

22. Roman G, Synthesis and characterization of aminomethylated 2-chloro-4-phenylphenols. Rev Chim (Bucharest), 2012; 63(3): 255-258.

23. Roman G, Chemoselective aminomethylation of bifunctional substrates: Carbonyl versus phenolic hydroxyl, carbonyl versus pyrazole and pyrrole versus phenolic hydroxyl as competing activating groups. Tetrahedron Lett., 2014; 55(6): 1229-1233.

24. Roman G, n-Propyl gallate as substrate in the Mannich reaction. Proc Rom Acad B, 2016; 18(3): 175-180.

25. Roman G, Mannich bases in medicinal chemistry and drug design. Eur J Med Chem., 2015; 89: 743-816.

26. Roman G, Năstasă V, Bostănaru AC, Mareş M, Antibacterial activity of Mannich bases derived from 2-naphthols, aromatic aldehydes and secondary aliphatic amines. Bioorg Med Chem Lett., 2016; 26(10): 24982502.

27. Sgaragli GP, Valoti M, Gorelli B, Fusi F, Palmi M, Mantovani P, Calcium antagonist and antiperoxidant properties of some hindered phenols. Br J Pharmacol., 1993; 110: 369-377.

28. Shelef LA, Liang P, Antibacterial effects of butylated hydroxyanisole (BHA) against Bacillus species. $J$ Food Sci., 1982; 47(3): 796-799.

29. Tramontini M, Advances in the chemistry of Mannich bases. Synthesis, 1973; 1973: 703-775.

30. Tramontini M, Angiolini L, Further advances in the chemistry of Mannich bases. Tetrahedron, 1990; 46(6): 1791-1837.

31. Tugrak M, Yamali C, Sakagami H, Gul HI, Synthesis of mono Mannich bases of 2-(4-hydroxybenzylidene)2,3-dihydroinden-1-one and evaluation of their cytotoxicities. J Enz Inhib Med Chem., 2016; 31(5): 818-823.

32. Us D, Berk B, Gürdal E, Aytekin N, Kocagöz T, Çağlayan B, Kurnaz IA, Erol DD, Mannich base derivatives of 3-hydroxy-6-methyl-4H-pyran-4-one with antimicrobial activity. Turk J Chem., 2010; 34(3): 447-456.

33. Vandghanooni S, Forouharmehr A, Eskandani M, Barzegari A, Kafil V, Kashanian S, Ezzati Nazhad Dolatabadi J, Cytotoxicity and DNA fragmentation properties of butylated hydroxyanisole. DNA Cell Biol., 2013; 32(3): 98-103.

34. Vijaya Bhaskar Reddy M, Chen SS, Lin ML, Chan $\mathrm{HH}$, Kuo PC, Wu TS, Preparation of a series of novel bichalcones linked with a 1,4-dimethylenepiperazine moiety and examination of their cytotoxicity. Chem Pharm Bull., 2011; 59(12): 1549-1554. 